\title{
INTEGRATING INFORMATION TECHNOLOGY INTO AND ACROSS THE CURRICULUM: A SHORT COURSE FOR SECONDARY STUDENTS
}

\author{
Eleanor B. Howe \\ Shady Side Academy \\ 423 Fox Chapel Road \\ Pittsburgh, PA 15238-2296 USA
}

\begin{abstract}
The installation of technology in the school library is only the first step in its effective use by students. Many search engines are not intuitively obvious to users, and although students love computers, they often need help with searching. The author combines the results of action research in the high school library with conclusions in the professional literature to argue that systematic formal instruction in electronic search skills is necessary for awareness of library software and competence in its use. The paper focuses on the why, what, when, where, and how of teaching electronic search skills to high school students.

The installation of information technology-hardware and software-is only the first step in providing the full range of its educational benefits for students. In order for students to realize the full potential of information technology, they must become efficient and effective users of that technology. The central question for school librarians is what type of bibliographic instruction is most likely to achieve that goal for students.

Educators, administrators, and parents want to know the educational benefits of any program for students, and this is as true for information technology as for other educational programs and expenses (Scheib, 1993). Information technology is expensive, and it competes with other programs with increasing costs. Therefore, it should be therefore justified in terms of its real educational benefits for students. If an investment in information technology does not yield improved student learning, the question may well be asked if that technology is worth the money.

The cost of providing education is increasing exponentially, and there is evidence that the public may not provide an ever increasing amount of funding. There may be a backlash from administrators, parents, and taxpayers if improved learning does not result from additional expenditures. While expenses may increase across the curriculum, funding cuts may be focused on a few departments which seem less essential. Indeed, retrenchment in spending on schools and school libraries has already occurred in the United States (NJ Gov., 1995; Olson, 1995; Sadowski, 1993). In California, Proposition 13 led to decreased funding for schools, which led to decreased funding for school libraries and library media specialists. The ultimate result of Proposition 13 has been a reduction in student literacy and information skills at both the high school and college levels (Gorman, 1995).
\end{abstract}

\section{WHY TEACH ELECTRONIC SEARCH SKILLS?}

\section{Information Technology Supports the Mission of the School}

In order to achieve goals and justify funding for hardware and software, school librarians should be prepared to make clear the multiple connections between student proficiency in information technology, increased student learning and use of resources, and educational missions (Scheib, 1993). Although each district and school may have its own mission, there are several common underlying themes such as delivering the curriculum, the development of cognitive abilities, the quality of student-teacher relationships, and the instillation of democratic values. Each of these can be strengthened by a school library program which utilizes information technology. 


\section{Deliver the Curriculum}

Information technology helps deliver the academic curriculum in a number of ways. Electronic indexes facilitate resource-based learning across the curriculum by improving student access to and use of existing print and electronic materials in the library. Information technologies such as union catalogs, electronic libraries, and the Internet enhance the collection which supports resource-based learning by providing access to remote traditional and electronic materials.

Computer literacy is an integral part of the curriculum in most schools; incorporating information technology can strengthen students' computer skills. Most students learn word processing in computer literacy classes, but they may know little about databases. Databases are an efficient means of storing and retrieving information, and they are used for such typical library resources as indexes, online catalogs, and full-text materials. Through instruction in information technology, students can increase their computer literacy by learning the structure and operation of databases, additional software, networks, and the Internet.

Information literacy is also part of the curriculum, and the efficient and effective use of new information technologies is an essential component of students' competency as lifelong learners and users of information. Both the increasing amount of accessible information and the widespread public availability of electronic resources call upon our students to develop even more information skills and become even more sophisticated in their choice of resources and their use of information. Electronic searching can be incorporated with traditional information skills into Eisenberg and Berkowitz's Big Six Skills (Eisenberg \& Berkowitz, 1988). For example, in the second skill, students should become knowledgeable of the variety of electronic as well as traditional resources found in the library, and they should know which of these resources are appropriate for their information need. In the third skill, they should become competent in developing, evaluating, and modifying a variety of electronic search strategies and statements in order to retrieve needed information from all types of materials. Moreover, in using resources on the Internet, students should be prepared to evaluate the authority of the source-something they could take for granted in library collections.

\section{Develop students' cognitive skills.}

In addition to expanding their knowledge of and access to available information resources, students who use electronic access tools practice a variety of thinking skills across Bloom's taxonomy (Bloom, 1956; Bodi, 1990). Knowledge and comprehension of the variety of traditional and electronic resources form the foundation of information literacy and are utilized in selecting appropriate materials for an information need. Analysis is used in topic definition and the generation of related, broader, and narrower search terms. Logical thinking skills are used in the selection of appropriate search strategies and in the development and modification of search statements using subject headings and Boolean operators. Information skills are applied in resource-based learning across the curriculum. Students learn to identify and assess citations in order to evaluate the results of their searches and select resources for their use. Evaluation of resources and information becomes even more important when the number of available resources is increased and especially when using the Internet. In preparing a written or oral report, students synthesize the information retrieved in a meaningful way related to their topic or hypothesis.

\section{Improve student-librarian relationships.}

The use of electronic access tools increases and enhances the contact between school librarians and students as they discuss appropriate resources, search strategies, and search statements for a particular information need. The school librarian performs as a competent, informed, and intelligent manager of information in a variety of print and electronic media. The school librarian who teaches a course in electronic search skills increases professional and personal contact with students.

\section{Strengthen democratic values.}

The appropriate use of information technology is predicated on democratic values which should be made explicit. The ethical use of information in terms of copyright and plagiarism is an even greater challenge when information technology provides students with the capability to copy, download, and print from full-text resources. Students should be aware of the temptations made possible by technology and their responsibility to abide by academic honesty and to respect fair use 
of copyrighted materials. Expensive hardware and software in the library are community resources which students should respect and share maturely. They should also respect and evaluate the authority and opinions of others found in the expanding universe of resources and information.

\section{Information Technology Supports School Library Missions} the school.

Information technology supports several goals of the school library in addition to those of

\section{Provide efficient access to the collection.}

Competent searching of electronic indexes, catalogs, and full-text resources provides improved physical and intellectual access to both traditional and electronic materials in the school library. Electronic indexes are quicker and more thorough than print indexes for sifting through materials printed over an extended period of time. While print indexes are efficient for one book or for one year of periodical publications, electronic periodical indexes enable the student to use one search to retrieve articles published over a number of years. They also enable keyword searching of abstracts or full-text resources.

\section{Increase utilization of the existing print collection.}

Electronic indexes and catalogs foster increased use of existing print materials. Most students would rather use an electronic than a printed periodical index, and in my library I have found increased use of hard copies of periodicals and articles since the installation of electronic indexes for these resources.

\section{Promote and facilitate resource-sharing among libraries.}

In resource-based learning, students may be encouraged to develop their own research interests, and most school libraries could not afford to provide the breadth and depth of collection needed to support them. State and regional union catalogs which are available in the school library on CD-ROMs or hard drives enable students to search for and obtain remote materials on topics of individual interest. For Example, the installation of the Pennsylvania online union catalog, ACCESSPA, on our Library Information Network made available to our students more than three million titles in 1300 special, public, academic, and school libraries across the state. The program also generates an interlibrary loan request form. While Shady Side Academy has been a net lender of materials to other libraries, Senior School students have received more than 450 books from other participating libraries. This means that our students have used resources currently worth about US $\$ 11,250$ from the collections of other libraries in the consortium.

\section{Improve student lifelong learning and information skills.}

The philosophy of reference service in special libraries is usually to bring a resource to the user - to bring a fish. The philosophy of school and academic libraries, on the other hand, is to teach students to be independent users of information-to teach them to fish. Public libraries fall somewhere in between (Harris, 1992). School librarians have successfully taught students to use the card catalog (Coupe, 1993). Now, we should teach them to use electronic resources effectively. At the very least we should devise instructional programs which will enable our students to utilize the multitude of traditional and electronic resources now available. Our students have access to the Internet and to a variety of OPACs and CD-ROMs in school and public libraries. They will find even more electronic resources in college and university libraries and campus networks. Information technology and electronic resources should, however, be kept in perspective. The use of print materials and access tools is still very important (Boardman, 1996).

Competent student use of information technology clearly supports school and school library missions and goals thereby justifies the large investment it requires. The question remains, however, whether students can learn to use information technology effectively by themselves or whether systematic instruction in that technology is necessary for them to utilize a wide range of cognitive skills and become efficient and effective users of the hardware and software. To answer this question it would be helpful to examine current progress toward the goal of preparing students to become competent users of information technology. 
There is at present little uniformity among the multitude of search engines for information software. The standardized professionally developed card catalog, which enabled patrons to walk into any library and use its major access tool, has been replaced by a multitude of commercially developed OPACs whose uniqueness is reflected in their individual and often creative names. This situation is compounded by the variety of search engines for the indexes and full-text resources found on CD-ROMs and the Internet. The use of this software, however, is not intuitively obvious to students or even to information professionals (Chen, 1993; Edmonds, Moore, \& Balcom, 1990; Hooten, 1989; Kenny \& Schroeder, 1992; Sandlian, 1995; Solomon, 1994). These electronic tools and resources do require new skills and have revived an interest in group bibliographic instruction to meet the needs of library users by at least enabling them to use the resources at hand (Allen, 1990; Bush \& Wells, 1990; Coupe, 1993; Dennis \& Stadthaus, 1991; Edmonds, Moore, \& Balcom, 1990; Fox \& Weston, 1993; Johnson et al., 1993; Kenny \& Schroeder, 1992; Kosuda, 1986; Manczuk \& Pasco, 1994; Martin, 1995; Miller \& Warmkessel, 1990; Nash \& Wilson, 1991; Nickerson, 1991; Wright \& Friend, 1991).

The professional literature indicates that librarians have not yet been successful in preparing students of all ages to use the information technology now available in libraries. Children in elementary, middle, and high school do not use effectively either the standard or specially designed juvenile OPACs found in school and public libraries (Chen, 1993; Edmonds, Moore, \& Balcom, 1990; Hooten, 1989; Sandlian, 1995; Solomon, 1994). Types of errors found when high school students use an OPAC include spelling and typing mistakes; conceptual and interpretive errors; and lack of knowledge of the library, the subject, and the online system (Chen, 1993). A survey at the Johns Hopkins University indicated that while college students are quite knowledgeable of the catalog card and the card catalog, they had difficulty using online catalogs and indexes (Coupe, 1993). Not all college students like to use OPACs and databases, and even those students who do are usually unaware of their own ignorance in using them (Kenny \& Schroeder, 1992; Nash \& Wilson, 1991; Warmkessel \& Carothers, 1993). A number of studies have concluded that college students cannot effectively use OPACs and cannot interpret the citations they retrieve (Bush \& Wells, 1990; Coupe, 1993; Fister, 1992; Greer, Weston, \& Alm, 1991; Kenny \& Schroeder, 1992; Martin, 1995; Nash \& Wilson, 1991; Scott, Trimble \& Fallon, 1995). Moreover, many college students think they are better searchers than they really are, they do not ask for help in using electronic resources, and they do not learn to use the OPAC or indexes by themselves over repeated time in the library (Allen, 1990; Coupe, 1993; Fox \& Weston, 1993; Kenny \& Schroeder, 1992).

This situation calls for attention from librarians from kindergarten to college since an information literate public depends on librarians at all levels (Gorman, 1995; Kemp, Nofsinger \& Spitzer, 1986). School librarians have an important role to play in enabling students of all ages to use information technology because one of our missions is to provide the resources and learning activities which will enable students to become lifelong learners and users of information (American Association of School Librarians \& Association for Educational Communications and Technology [AASL \& AECT], 1988). To achieve this goal school librarians should not only install information technology but also develop an information skills program which will enable students to use effectively the electronic resources both in the school library and in the world beyond.

I decided to develop such a program at the Shady Side Academy Senior School after installing a local area network in the library. In order to present a relevant and developmentally appropriate information skills program for my students, I needed to determine the existing level of information skills among students who were ready to graduate. I therefore initiated an annual survey of library use and electronic information skills among seniors. Since there had been no prior systematic instruction in electronic information skills, this survey would indicate what the students were able to learn on their own and by inference as well as what I would have to teach in order to bring them to the desired exit-level of skills.

The results of three years of these surveys of information skills indicated that senior students did not find or learn to use electronic resources on their own during two years of their availability on the library network. The two least used electronic resources on the network were highly relevant to their resource-based learning in health, history, and English composition. This finding underscores the significant role that the school librarian plays in exposing students to available materials, even electronic resources (Howe, 1997). 
Secondly, the surveys indicated that more students actually used electronic resources than claimed to know how to use electronic search skills. Specifically, more students actually used Boolean searches than claimed to know how to use them and more students claimed they knew the difference between subject and keyword searches than actually used a keyword search (Howe, 1997). This finding supports the need for instruction in basic search strategies and statements.

The results of my action research at Shady Side Academy are similar to the conclusions of public and academic librarians that students cannot effectively use electronic information skills without instruction, that self-assessment exceeds performance, and that students do not learn electronic information skills on their own (Coupe, 1993; Fox \& Weston, 1993; Greer, Weston, \& Alm, 1991; Kenny \& Schroeder, 1992; Nash \& Wilson, 1991; Sandlian, 1995). The professional literature and my action research also support the more general conclusions that the knowledge and skills needed to solve problems with technology are quite different from those of a paper environment, that students do not automatically apply critical thinking skills to their use of electronic access tools, and that systematic instruction is necessary to ensure that all students become effective and independent users of information and libraries (Allen, 1990; Bush \& Wells, 1990; Coupe, 1993; Dennis \& Stadthaus, 1991; Fox \& Weston, 1993; Harris, 1992; Johnson et al., 1993; Kenny \& Schroeder, 1992; Manczuk \& Pasco, 1994).

In addition, informal observation of my students over the past four years leads me to believe that the popular consensus that students love and instinctively know how to use computers is not necessarily true in secondary school libraries. Some students prefer the card catalog and enter high school with poor keyboarding and spelling skills-two skills which are necessary for successful use of an OPAC (Sandlian, 1995). The crowds of students who arrived in the library after installation of the network were generally more interested in hacking than in searching for information. Students who love computer games and programming are not necessarily good at electronic searching; different interests and skills are involved.

In light of this evidence, it is hard to deny that systematic instruction in electronic search skills is necessary to ensure that students have the skills to manage information efficiently and effectively in both traditional and electronic formats and to meet the goals of an information literacy program which supports school and library missions. Professional guidelines exhort us to provide "systematic learning activities" (AASL \& AECT, 1) and the evidence suggests that this is needed in the form of course instruction.

\section{WHAT TO TEACH ABOUT ELECTRONIC SEARCH SKILLS}

Which skills in information technology should be taught flows from the specific context of the school-the students, the goals of the information literacy program, the available resources, and the available time in the schedule as well as the missions of the school and the library program. What is taught should prepare students to use resources they will find within and beyond the school setting and should be incorporated into the district K-12 scope and sequence of information skills.

Within a specific school, an information skills program should be developmentally and curricularly appropriate. School librarians planning an information technology program should take into consideration the entry-level skills of incoming students, the range of students' physical and cognitive abilities, students' interests, the school curriculum, applications in resource-based learning, and the desired exit-level skills for students. Minimal skills for the use of information technology include keyboarding, spelling, the interpretation of citations; and knowledge of access points, the classification system, and information resources (Chen, 1993). Instruction should be designed to move students from entry-level to the desired exit-level of information skills.

In order for students to develop lifelong learning skills, high school librarians should prepare them to use not only the resources in their own school library but also those they are likely to encounter in public and academic libraries since comprehensive instruction is not consistently available in those libraries (Harris, 1992). There is evidence that information skills learned in high school do carry over into college (Coupe, 1993; Kosuda, 1986). Although Kester (1994) found that few information skills were transferred from high school to college, the results of this study may reflect the particular types of survey questions, students, and high school information skills programs under consideration. 
Retention and transferability of information skills may be more likely when those skills are presented systematically within the context of general concepts which can apply to other library situations and in a separate course rather than either course-integrated or point-of-use instruction (Fox \& Weston, 1993). Chen's (1993) finding of many errors of basic library concepts among high school students using an OPAC indicates that information concepts should be taught and that instruction in the mechanics of operation is not sufficient for information literacy. Instruction and comprehension of basic information concepts, and not just point-of-use applications, may be necessary for students to become lifelong learners and users of information (Jacobson \& Jacobson, 1993).

Instruction in concepts is feasible for most high school students since most adolescents are in Piaget's formal operations or abstract level of cognitive development (Elkind, 1994; Jacobson \& Jacobson, 1993; Woolfolk \& McCune-Nicolich, 1984). Information concepts which can be presented and applied in a course in information technology include database structure, network structure, the functions and access points of indexes, the research process, the search process, types of search strategies, Boolean operators, the classification system, and the ethical use of information (Jacobson \& Jacobson, 1993). Each of these concepts lays a foundation for lifelong learning and information literacy and each should be made concrete through a practical demonstration or application at the time of instruction (Jacobson \& Jacobson, 1993).

Academic librarians have enumerated the information skills needed by college students: awareness of library resources and services; knowledge of access points for card and online catalogs; and the abilities to select and focus a topic, to identify and use correctly search strategies and statements, to distinguish types of indexes and citations, and to locate and evaluate materials (Allen, 1990; Bush \& Wells, 1990; Coupe, 1993; Fox \& Weston, 1993; George, 1988; Greer, Weston, \& Alm, 1991; Kenny \& Schroeder, 1992; Kester, 1994; Nash \& Wilson, 1991). Since these skills are also needed to function in public libraries at the adult level, high school librarians would be wise to consider them as a list of desirable exit-level skills and incorporate as many as possible into their information skills programs.

Resources to be used in instruction in information technology should be available in the school library and include as many as possible of the basic genre: catalogs, indexes, full-text resources, search engines on the Internet, and specific relevant authoritative and valuable information resources available on the Internet. Consider at the time of purchase how suitable each program is for instruction. Are both the content and the search engines developmentally appropriate for your students? Do menus, nomenclature for search strategies, and features exemplify the concepts you want to teach? Can the content of the software be used in skills instruction and related to other courses in the curriculum?

\section{WHEN TO TEACH ELECTRONIC SEARCH SKILLS}

In secondary schools it is advisable to teach the correct use of a resource when it is first available for use. Students may develop incorrect assumptions and bad habits when use precedes instruction, and, as noted above, the professional literature suggests that students do not learn to use information technology on their own, even with repeated exposure. Information technology should be taught the first year a student arrives in a secondary school so that students are aware of and can use those resources throughout their years in the school.

The other major question of when to teach information technology concerns point-of-use instruction versus instruction in a separate course. This is part of the larger discussion of whether the goal of bibliographic instruction is specific applications or lifelong use of information. The concepts needed for lifelong learning strategies are not usually addressed in point-of-use instruction which necessarily focuses on specific resources. The ideal bibliographic instruction program at the college level includes group instruction, printed guides or computer aided instruction, and one-on-one reference service (Greer, Weston, \& Alm, 1991); Johnson et al., 1993). This may be a good model for high schools as well.

While colleges and universities have developed a variety of means of offering bibliographic instruction in information technology, separate courses do exist and are successful at the college level (Bush \& Wells, 1990; Dennis \& Stadthaus, 1991; Fox \& Weston, 1993; Johnson et al., 1993; Kosuda, 1986; Martin, 1995; Miller \& Warmkessel, 1990; Nickerson, 1990; Wright \& Friend, 1990). A 
separate course offers advantages over point-of-use instruction, and college students do enroll in a separate elective course in information literacy in order to apply the knowledge gained from that course to assignments in other courses (Dennis \& Stadthaus, 1991; Kosuda, 1986).

A separate course in basic information literacy is suitable and recommended at the secondary level for a number of reasons. First, separate instruction is developmentally appropriate for young adults. Adolescents are moving into the abstract level of cognition and also have increased capacity for both short-term and long-term memory compared to younger children (Elkind, 1994). Second, all students need these skills, not just those in courses whose teachers bring them to the library for resource-based learning. Third, even those teachers who bring their classes to the library for instruction do not have sufficient time to allow the school librarian systematically to teach concepts or electronic search skills as an integrated information skill during their class period. Fourth, there is evidence that high school students can apply concepts learned in instruction to applications at other times (Chen, 1993; Smeltzer, 1996). Finally, if something is worth knowing and learning, it is worth teaching systematically with an orderly progression of concepts and skills. This is the foundation of teaching and learning in other courses. Most librarians would admit that their electronic search skills improved after a course in online searching.

Point-of-use instruction also has an important role in the secondary school. Individual or group instruction in the use of additional course-specific electronic resources could be integrated into those courses which use them for resource-based learning. In this way information technology skills may be integrated and utilized across the curriculum even though basic concepts and skills are taught in a separate course. Personal assistance to the individual researcher is also very effective.

\section{HOW TO TEACH ELECTRONIC SEARCH SKILLS}

Recommendations for how to teach information technology flow from what and when to teach. Obviously, such instruction should be developmentally appropriate in methods, timing, and resources. The following recommendations for a course at the high school level are derived from my own experience teaching a mini-course in electronic search skills three times a year for three years and are supported by the professional literature as noted.

Such a course should be a carefully planned orderly progression of topics, concepts, and skills. There should be presentation in concepts and timely practice of those concepts at the keyboard (Ala \& Cerabona, 1992; Jacobson \& Jacobson, 1993; Kosuda, 1986). Individual learning is preferred to cooperative groups so that each student may have his or her own choice of topic to research and may experience reinforcement of concepts and skills through repeated practice and exposure to multiple search engines. Moreover, when there are not sufficient workstations for each student to have his or her own, those students without a keyboard often begin to lose interest. Individuals can work well together, however, on generating search terms and search statements (Jacobson \& Jacobson, 1993; Warmkessel \& Carothers, 1993).

Allow students their choice of topic to research since they will be searching for, locating, and reading a number of resources. When students select the subject of their research, the process and product may be of greater interest and they may see more applications (Dennis \& Stadthaus, 1991; Johnson et al., 1993). It may also be possible to integrate the results of the student's searching on a topic of choice into another classroom course. The information from articles and books retrieved and read can be put in an annotated bibliography or research report and turned in to the teacher of a relevant course after grading by the school librarian. In this way information technology presented in a separate course may be integrated across the curriculum.

In designing instruction for a separate course, ensure that students utilize the range of thinking skills in Bloom's taxonomy: knowledge, comprehension, application, analysis, synthesis, and evaluation (Bloom, 1956). When students are gaining knowledge and comprehension and using higher order thinking skills, the course is more likely to contribute to learning and to school and library missions.

In even a brief course students can gain new knowledge of resources and access tools, basic concepts of information access and electronic searching, specific search engines, methods to evaluate the results of searches, organization of the library, and citation format. Students may also gain 
knowledge of subject matter when the results of their searches are used to create an annotated bibliography or a research report.

Student comprehension of concepts and skills can be assessed through observation at the keyboard, printouts from searches, worksheets, practicum questions, written or oral reviews and tests, and bibliographies (Feinberg \& King, 1992).

Concepts, search strategies and statements, and methods of evaluating searches and citations should each be applied at the keyboard with various electronic resources. Students apply their knowledge of resources when they select an appropriate database to search. They apply their knowledge of search strategies and statements to the type of information resource they want. They apply evaluation techniques in modifying searches and in selecting materials to use. They apply their knowledge of library organization as they locate library resources retrieved on their searches. They apply their knowledge of citation format to distinguishing books from articles and to the creation of a bibliography of resources found with electronic searching.

Students use analytical thinking skills when they define a topic and generate related, broader, and narrower search terms. They analyze the type of information and resources needed in order to select appropriate access tools and materials. In writing an annotated bibliography, they analyze resources. Students who write a research report synthesize the information found in all resources into a meaningful and well organized text.

Evaluation is an especially important skill when using information technology. Students should learn and apply the two basic methods of evaluating the results of searches so that they can modify strategies and statements in order to improve the yield. Students should be able to evaluate citations in order to select those best suited to their topic. Students with access to the Internet should be aware of the importance of evaluating the authority of the source of the information they have retrieved. Ultimately students learn to evaluate resources and information for their accuracy, authority, and bias, although this may be more common in college than in high school (Bodi, 1990).

Lesson plans may be based on Madeline Hunter's design for effective teaching: statement of purpose, modeling by the instructor, student practice guided by the instructor, and finally independent practice by the student (Henson, 1993; Jacobson \& Jacobson, 1993). The computer screen used for modeling may be projected by means of a liquid crystal display.

\section{WHERE TO TEACH ELECTRONIC SEARCH SKILLS}

Teaching a basic course in electronic search skills requires a local area network of contiguous workstations so that the resources are simultaneously available for students during instruction. The network should have a workstation for each student, but if this is not possible two students may share one. The workstations should be in a quiet location removed from other students using the library since teaching, student interaction, and printing generate noise. A small computer lab in a separate room in the library is ideal. If this is not available and the school network includes library resources, you might arrange to teach electronic search skills in the computer lab or writing center. You may want to present concepts in a classroom where you can use an overhead projector or chalk board and students have room to take notes.

A basic course in electronic search skills could be included in the curriculum in either a library skills or information literacy course, a computer literacy course, or a research skills course. Including electronic search skills in a computer literacy or research skills course provides a model of interdepartmental, interdisciplinary cooperation and offers another means of integrating information skills across the curriculum.

\section{CONCLUSIONS}

Systematic instruction of electronic search skills in a separate course clearly supports school and library missions. Such instruction is necessary to justify the investment in information technology because the evidence suggests that students do not learn to be efficient users of that technology on their own. Concepts, skills, and resources used in instruction should be developmentally appropriate, and students should choose their own topics and utilize the range of thinking skills in Bloom's taxonomy. Information technology may be integrated into the curriculum through a short course for all students offered as part of library skills, computer literacy, or research 
skills. Such a course may be integrated across the curriculum by allowing students to research a topic for another course and by providing students with the concepts, skills, and resources they can use for assignments in other courses throughout their school years. In order to serve the needs of students and the curriculum and to meet the missions of school and library programs, a comprehensive high school bibliographic instruction program should begin with a separate course for all students and continue with course-integrated instruction in specific resources, printed materials, and personal oneon-one or assistance. In this way, school librarians will best prepare students to be lifelong learners and users of information.

\section{REFERENCES}

Ala, J., \& Cerabona, K. (1992). Boolean searches-a life skill. School Library Journal, 38(11), 42. Allen, G. (1990). CD-ROM training: what do the patrons want? $R Q, 30(1), 88-93$.

American Association of School Librarians and Association for Educational Communications and Technology (1988). Information power: Guidelines for school library media programs. Chicago: American Library Association.

Bloom, B. (1956). Taxonomy of educational objectives. New York : David McKay.

Boardman, E.M. (1996). We need two libraries: One electronic, one book. Book Report, 14(5), 17.

Bodi, S. (1990). Through a glass darkly: Critical thinking and bibliographic instruction. Catholic Library World, 61(6), 252-256.

Bush, R.B., \& Wells, M.R. (1990). Bibliographic instruction for honors students: The University of Buffalo experience. Research Strategies, 8(3), 137-143.

Chen, S.H. (1993). A study of high school students' online catalog searching behavior. School Library Media Quarterly, 21(4), 33-39.

Coupe, J. (1993). Undergraduate library skills: Two surveys at Johns Hopkins University. Research Strategies, 11(4), 188-201.

Dennis, N., \& Stadthaus, A. (1991). Teaching information technologies in a classroom setting. Computers in Libraries, 11(Jan 1991), 17-19.

Edmonds, L., Moore, P., \& Balcom, K.M. (1990). The effectiveness of an online catalog. School Library Journal, 36(October 1990), 28-32.

Eisenberg, M.B., \& Berkowitz, R.E. (1988). Information problem-solving: The Big Six skills approach to library \& information skills instruction. Norwood, NJ : Ablex.

Elkind, D. (1994). A sympathetic understanding of the child: Birth to sixteen (3rd ed.). Boston : Allyn and Bacon.

Feinberg, R., \& King, C. (1992). Performance evaluation in bibliographic instruction workshop courses: Assessing what students do as a measure of what they know. Reference Services Review, 20(2), 75-80.

Fister, B. (1992). The research processes of undergraduate students. Journal of Academic Librarianship, 18(3), 163-169.

Fox, L., \& Weston, L. (1993). Course-integrated instruction for nursing students: How effective? Research Strategies, 11(2), 89-99.

George, M. (1988). What do college librarians want freshmen to know? My wish list. Research Strategies, 6(4), 189.

Gorman, M. (1995). The domino effect, or why literacy depends on all libraries. School Library Journal, 41(4), 27-29.

Greer, A., Weston, L., \& Alm, M. (1991). Assessment of learning outcomes: A measure of progress in library literacy. College \& Research Libraries, 52, 549-557.

Harris, R.M. (1992). Bibliographic instruction: The views of academic, special, and public librarians. College \& Research Libraries, 53, 249-256.

Henson, K.T. (1993). Methods and strategies for teaching in secondary and middle schools (2nd ed.). White Plains, NY: Longman.

Hooten, P.A. (1989). Online catalogs: Will they improve children's access? Journal of Youth Services in Libraries, 2(Spring 1989), 267-272.

Howe, E.B. (1997). Using student surveys to build and evaluate an information skills program. School Libraries Worldwide, 3(2), forthcoming. 
Jacobson, F.F., \& Jacobson, M.J. (1993). Representative cognitive learning theories and BI: A case study of end user searching. Research Strategies, 11, 124-137.

Johnson, W.K., Todaro, J., Byrd, T.S., Myers, R., Anderson, L., Sowell, C.L., Miller, M.A., Kiel, R., \&. Thorish, T. (1993). Immodest rebuttal: A community college perspective. Research Strategies, 11(2), 100-105.

Kemp, B.E., Nofsinger, M.M., \& Spitzer, A.M. (1986). Building a bridge: Articulation programs for bibliographic instruction. College \& Research Libraries, 47, 470-474.

Kenny, R.F., \& Schroeder, E. (1992). An evaluation of a training and assistance program for the CDROM databases: Reflections on the process. Reference Services Review, 20(2), 41-48.

Kester, D.D. (1994). Secondary school library and information skills: Are they transferred from high school to college? Reference Librarian, 44, 9-17.

Kosuda, K. (1986). Bibliographic instruction at a small goal-oriented campus. Catholic Library World, 58(2), 86-90.

Manczuk, S. \& Pasco, R.J. (1994). Planning for technology: A newcomer's guide. Journal of Youth Services in Libraries, 7 (2), 199-206.

Martin, R.P. (1995). Integrating library computer skills into a credit course. Association of College and Research Libraries. National Conference, Pittsburgh, PA.

Miller, S.M., \& Warmkessel, M.M. (1990). Bibliographic instruction, history of the book, and poststructuralism: An unlikely combination helps to expand the critical thinking skills of undergraduates. Research Strategies, 8(2), 59-65.

Nash, S., \& Wilson, M.C. (1991). Value-added bibliographic instruction: Teaching students to find the right citations. Reference Services Review, 19(1), 87-93.

Nickerson, G. (1991). Developing in-house tutorials. CD-ROM Professional, 4(5), 45-47.

NJ Gov. labels school librarians "non-instructional." (1995). School Library Journal, 41(4), 14.

Olson, R. (1995). Cincinnati school librarians to be reassigned, district announces. School Library Journal, 41(5), 12.

Sadowski, M.J. (1993). Jobs in jeopardy as schools look for cheap alternatives. School Library Journal, 39(5), 10-11).

Sandlian, P. (1995). Rethinking the rules: The story behind Kid's Catalog. School Library Journal, 41(7), 22-25.

Scheib, C.M. (1993). Planning for networking in school libraries. Computers in Libraries, 13(4), 2226.

Scott, J., Trimble, J.A., \& Fallon, L. (1995). "@\&!\#@ this computer and the horse it rode in on": Patron frustration and failure at the OPAC. Association of College and Research Libraries. National Conference, Pittsburgh, PA.

Solomon, P. (1994). Children, technology, and instruction: A case study of elementary school children using an online public access catalog (OPAC). School Library Media Quarterly, 23(Fall 1994), 43-51.

Smeltzer, T.L. (1996). No more trivia questions. Book Report, 14(5), 15.

Warmkessel, M.M., \& Carothers, F.M. (1993). Collaborative learning and bibliographic instruction. Journal of Academic Librarianship, 19(1), 4-7.

Woolfolk, A.E., \& McCune-Nicolich, L. (1984). Educational psychology for teachers (2nd ed.). Englewood Cliffs, NJ : Prentice-Hall.

Wright, C., \& Friend, L. (1991). A mobile online/CD-ROM workstation for demos and instruction. Online, 15(3), 74-76. 